\title{
Review
}

\section{Boron's Importance in Plant Development and Growth: A Review}

\author{
M. A. Abou Seeda ${ }^{\#}$ F.A. Hellal, S.A.A. EL Sayed and E. A. Abou ELNour* \\ Plant Nutrition Dept. and *Fertilization Technology Dept., National Research \\ Centre, Dokki, Postal Code: 12622, Cairo, Egypt.
}

T'S AN IMPORTANT micronutrient for plant nutrition, the availability of boron is important for growth parameters. The physiological role in plants controlled by boron and its affinity to environment, generally accommodated to excelling appreciating the assignment of boron in plants.

Interdict of hydrogen ion deliver due to boron draw up and amends in plant substrate demonstrated boron association in cell wall actions it's a unique micronutrient depends for common plant growth and optimum yield of crops. Its concentration in soil and plant not only varies with soil, plant, but also its overdose or defect, may affect the plant growth and production. Boron in soils gradually influence by several factors among of its, soil $\mathrm{pH}$, organic matter, nutrient interactions, and plant species. Deficiencies of boron cause a reduction of yield production and quality. However, the toxicity was gradually observed in the presence of $\mathrm{Ca}$ application. Function of boron in plant observed in cell division, seed development and sugar transport in plant. Plant needs trace amount of boron for plant growth as compared with primary nutrients. The aim of this review is to understand the physiological duty of boron element in plants.

Keyword: Boron toxicity, deficiency and translocation in plant tissues, Plant physiology

\section{Introduction}

Boron demerit was more inclusive than imperfection of any other plant micronutrient (Gupta, 1979). Walsh \& Golden (1953) reported that in sandy soils, boron can be reached out and unavailable for plants. Sufficient amount of boron nutrition is captious for both of high quantity and quality of yield. Deficiency of boron causes divers inspectional, physiological, and biochemical changes, representing derivative decrepit. Due to the expedition large discrepancy of features that supersede boron contradiction, crucial the primary dominant function of it and considerably assert in the fertilization of plant

Dell et al. (1997), Reinbott (1995) and Shkolnik (1984) summarize boron reports from agricultural and physiological perspectives. A blanket revise of the early work by Gauch \& Dugger (1954) was segregated into deferent separated parts, each part depicting an altered credible location of boron exploit. Other one unifying, postulate that regain composure, copious of the essentially of boron on yield production and advance mental actions (Lewis, 1980 and Lovatt \& Dugger, 1984).

Currently, research has advanced for interpretation that boron associated in three important directions of physiological reaction in plant cell, besides its main function in cell walls, membrane, and metabolic actions. Shorrocks (1997), illustrated that, boron is widely distributed in nature both lithosphere and hydrosphere (Gupta \& Solanki, 2013; Erike \& Nelson, 2012 and Mortvedt, 2010). Boron is important for many plants, and its bio-availability in soil and water is rather important for agronomics production (Bellaloui et al., 2009a). However, under draught condition, boron may accumulate in soil to levels that causing a toxicity to plant, and reduce yield production (Reid, 2007b and Tanaka \& Fujiwara, 2007). 
Boron is adapted to form complexes with other compounds particularly with hydroxyl groups in cis-configuration. Borate esters with a piose residue of rhamno-galacturonan II (RGII) is the main functions of boron in plants (Kobayashi et al., 1996). The composition may be rather important for the function of cell wall. (O’Neill et al. 2004) which provide indicatively to control porosity of cell wall (Fleischer et al. 1999) as well as tensile strength (Ryden et al. 2003). Boron deficiency can cause irregularly of the cell walls and a gradually decreased the formation of dimer RG-II (Matoh et al., 1996). Noguchi et al. (2003) and Bellaloui et al. (2013) reported that the minimizing of grade of cross-linking particularly in cell walls of Arabidopsis bor1-1 mutant due to lower boron supply.

\section{Uptake of boron by plants}

Many forms of boron present in soil solution. However $\mathrm{B}(\mathrm{OH})_{3}$ particularly at $\mathrm{pH}$ values ranged between 5.5-7.5. is the most plentiful form. Boric acid uptake can be subjected by three absorption appliance: (i) Passive absorption across lipid bilayer, (ii) Active absorption by (MIP) channel, and (iii) An energy dependent high-affinity transport system induced in response to low boron supply, which is mediated by BOR transporters (Tanaka \& Fujiwara, 2007). The availability of boron absorption is subjected through a passive absorption that involves mostly $\mathrm{B}$ diffusion across lipid bilayer. Permeability coefficient were both calculated theoretically and experimentally for boric acid, by Ali, et al (2013) and Gupta \& Solanki (2013). Dordas \& Brown (2001) and Stangoulis et al. (2001), support this, since boron can cross membranes via passive absorption to reach boron requirements for plant. Dannel et al. (2002), Dordas et al. (2000) and Bellaloui et al (2013) observed that in squash roots, diffusing across plasma-membrane vesicles was slightly depressed by mercuric chloride, similar finding were reported by Trivedi (2015).

\section{Role for boron in cell wall structure}

Carpita (1987), indicated that the mechanical character of developing of cell walls adapted through the reaction between its main components, polymers of cellulosic structure and hemi cellulosic and pectic polysaccharides in matrix media. Trivedi (2015), Planchet et al. (2011) and Bellaloui et al. (2013) reported that the formation of esters borate through the interaction with hydroxyl groups of cell wall has been advanced as a mechanism for interacting with cell wall polymers. Casassa et al. (1986) and Sarquis (1986) explained this phenomenon and sliding properties of "slime". The interaction of both hydrogen and hydroxyl groups of polyvinyl alcohol, which is more stable on a furanoid ring were illustrated by Carpita (1987).

Boron can be protected by $\mathrm{Ca}$ in the cell wall through forming of crosslinks in pectin (Clarkson \& Hanson, 1980). Results by Yamaouchi et al. (1986) supported this idea through, low concentration of boron in tomato plant contained low calcium. O'Neill et al. (1996) reported that, ester of borate formation was situated on 2- $\mathrm{C}$ and 3-C of two of the four 30-linked apiosyl residues of dimeric RG-II they also reported that the dimeric RG-II-B covalently crosslinks the cell wall pectic matrix in dicots. Authors also indicated that in non-graminaceous monocots, and graminaceous plants, though the pectin content of the grasses is much lower than that of the other species. Hu et al. (1996) observed that in boron-deficient, cell structure of bean root accommodate, minimum levels of hydroxyl Proline with proteins content, comparing with those of normal condition.

\section{Membranes and membrane-associated reactions}

Studies on new cell formation explained the problems associated along low concentration of elements. These make dramatically changing in membrane activity actuate by application of boron to boron-deficient tissues (Planchet et al., 2011 and Bellaloui et al., 2013). Despite it is not big mainly, comparing to those in cell fractions, and gradually significant for ion uptake. Borondeficient in sunflower roots phosphorus was decreased and gradually recovered after boron added within few minutes (Goldbach, 1984 and Goldbach et al., 1990). Boron deficiency caused a gradually reduced the concentration of ferric cyanide by about $50 \%$ induced net proton release, occurring only in the presence of auxin, and was rather important for auxin stimulation of ferric cyanide-induced proton release in suspension cultures of carrot and tomato. Schon et al. (1990) illustrated that in sunflower an important hyper polarization of the membranes within 3 min due to boron applied were observed. Boron nutrition was more important for conserving the "reducing atmosphere" in the apoplast in order to animate nutrient uptake supported by Brown (1979).

Boron is important for keeping the reduced ascorbate form at the cell wall $/$ membrane interface by stimulating NADH oxidase. It is note admirable that both forms have been linked with 
plant growth processes (Gonzales-Reyes et al., 1994 and Hidalgo et al., 1991). Barr et al. (1993) postulated that deficiency of boron stimulated the hyperpolarization of root membranes, and increase ferricyanide-dependent HC release, ATP-ase activity, NADH -oxidase activity, and ion transport. Cakmak et al. (1995) established the role of K- deficient, sucrose, phenolic, and amino acids in boron deficient in sunflower leaves.

\section{Nitrogen fixation and nitrate assimilation}

The importance of boron for fixation of nitrogen has been reported by several researchers. Microorganisms and actinomycetes require boron element for stability in their vesicles envelopes which keeping nitrogenase from inactivation by oxygen under nitrogen fixation (GarcíaGonzález et al., 1990). Bolaños et al. (1993) illustrated the mechanism of boron particularly in nitrogen fixer-legume interaction, Bolaños et al. (1996) noticed that, boron can be considered as important element for nodulation processes (Bonilla et al., 1997). Several researches reported that importance of boron for nitrogen absorption and minimize nitrate reductase and stimulating of nitrate accumulation. Shen et al. (1993) explained such phenomenon by the duty of boron in assisting the progressing of nitrate absorption as well as synthesis of proteins. Consequently, Ruiz et al. (1998a) postulated that plants when affair to boron deficient in short time gradually diminished the root system and leaf nitrate contents, as well as the concentrations of magnesium, calcium and potassium (Planchet et al., 2011; Trivedi, 2015) or phosphate (Camacho- Cristóbal et al., 2005). Decreasing of nitrate uptake by plant growing in media with low boron content may contribute to the absorption of ammonium between asparagine synthetize in the roots of tobacco (CamachoCristóbal \& González-Fontes, 2007).

\section{Secondary metabolism and oxidative stress}

Metabolism of phenolic compounds in plant cells controlled by boron concentration in growing media, and gradually increase duty the stimulation of the specific enzyme (Bellaloui et al., 2009a and Planchet et al., 2011). Lower concentration of boron actuated both quantitative and qualitative changes in the phenolic compounds in plants (Shahzad, 2011). Causing undetectable polyamine/ phenolic compounds low concentration conditions of boron was observed particularly in tobacco plants (Camacho-Cristóbal et al., 2005), increasing the activity of polyphenoloxidase activity (Camacho-Cristóbal et al., 2002), and changing phenolic compounds into quinones. It has been postulated that loss the integrity of cell membrane at low concentration of boron stimulates the accumulation of phenolic and their oxidation products (Cakmak \& Römheld, 1997 and Kobayashi et al., 2004). Under aluminum stress, boron encourage the accumulation of glutathione levels in sunflower and maize plants (Ruiz et al., 2006) and gradually support and stimulates the antioxidant (Corrales et al., 2008).

\section{Toxicity of boron}

Toxicity of Boron is rather problem which created significantly in crop yield in particularly in arid and semi-arid areas as in Egypt, characterizing by alkalinity and salinity properties under scarce and low rainfall and leaching of boron. In addition, intensive fertilization and using of irrigation water with high concentration of boron may increase the accumulation of boron in soil (Nable et al., 1997). Toxicity effects of boron can be effected on plants cells, acclimatize metabolism, reducing root cell separation, minimize chlorophyll contents and rates of photosynthetic, and reduce lignin content, (Reid, 2007b). They also reported that high concentration of boron may reduce the plant growth (biomass) (Ali et al., 2013).

Increasing level of boron created a toxicity symptoms on old leaves which characterized by marginal or tip chlorosis (Marschner, 1995 and Roessner et al., 2006). Boron toxicity is not bright abundant as described before. Three main causes have been explained the interaction of boron element with the hydro-oxides compounds in the position of cis (i) adaptation of the structure of cell, (ii) metabolic confusion such as ATP, and (iii) adaptation of cell separation and advancement (Reid et al., 2004). They reported that no attestation to reinforce the assumption of high level of boron resulted to osmotic accentuation (Reid et al., 2004). Growth was completely reserved by the presence of boron concentrations ranging between 1-5 $\mathrm{mM}$ and was not created by boron itself either energy supply or reserved of protein synthesis, but to the toxicity to fresh tissues, animate in brightness by photo oxidative stress (Reid et al., 2004 and Bellaloui et al., 2009a).

\section{Boron-toxicity tolerance and salt stress}

Nable et al. (1997) stated that, concurrent emphasis by toxicity of boron and salinity can be subjected either by irrigated water with high concentration of boron and salts, or by presence of huge amounts of salts as well as boron, commonly 
in arid regime (Marschner,1995 and Nable et al., 1990). Recently, many reports indicated that combination of high level of boron and saline may cause slightly toxic on growth than expected one. Bonilla et al. (1997) reported that advancing both elements boron and calcium contributes can be stimulate tolerance effects and, improving and enhancement the growth parameter salt affected soils. Nable et al. (1990) stated that the assortments of boron tolerant are distinguished by diminishing boron content in plants comparing to the other one, these phenomenon, perhaps due to the decreasing the uptake of boron in both roots and shoots. In this concern, tolerant of boron- in the Sahara clarified by its excessive adeptness to boron concentration. As earlier described, BOR1 is an efflux-type borate carrier inquired for the movement of boron from roots to shoots particularly in the absence of boron added (Takano et al., 2002). However in the attendance of high concentration of boron to be toxic levels BOR 1 is completely corrupt through endocytosis (Takano et al., 2005), and over announcement of BOR1 gene does not result in a quality of yield production (Miwa et al., 2006). In the barley research particularly, landrace Sahara 3771 results indicated that both Bot1, a BOR1 ortholog has been identified, as the gene dependable for boron toxicity indulgence. Its accommodate about four times additional Bot1 gene than the boron in catholic (Sutton et al., 2007). Additional, it was observed that Sahara Bot1 characterized by high protein content amplitude in order to provide boron tolerance in yeast than Clipper Bot1 or Arabidopsis BOR1.

\section{Boron and gene expression}

Many researchers reported that low boron content may alter the announcement consistent of the genes particularly for $\mathrm{N}$ - assimilation (Redondo-Nieto et al., 2001 and CamachoCristóbal \& González-Fontes, 2007), oxidizing agent accentuation (Kobayashi et al., 2004), the absorption of boron by plants (Takano et al., 2006 and Kasajima \& Fujiwara, 2007), and cell structure of plant (Camacho-Cristóbal et al., 2008). On the other hands, there no fair attestation to elucidate clamour the beacon came from the low concentration of boron is carry to nuclei of the cell. Kobayashi et al. (2004) advanced a fast beacon will gradually move from the cell wall to the cytoplasm may require for gene induction after the cellular redox none stabilize stableshed under low level of boron. Goldbach \& Wimmer (2007) reported the alter in the increments of boron might guide to a automated avalanche of beacons continuing into the cytoplasm through the cell wall-plasma membrane-cytoskeleton continuum, with the conceivable association of AGPs. This idea has been bolstered by the act, since the boron denial guide to changed polymerization forms of cytoskeletal proteins accumulation (Yu et al., 2003). González-Fontes et al. (2008) advised that the impersonation of boron as a cellular beacons accomplished of butting with duplication factors, which could clarified why the announcement of several genes necessitated in moratorium physiological developing are fasted affected when affair to the low concentration of boron. In accession to that, there is an interaction between boron and calcium since the feasibility that boron is influencing calcium-arbitrated beaconing (Bolaños et al., 2004a). Additional studies should be headquarter to classify the interaction as well as their activity in plant physiology.

\section{References}

Ali, M.A., Tariq, N.H., Ahmed, N., Abid, M. and Rahim, A. (2013) Response of wheat (Triticum aestivum L.) to soil applied boron and zinc fertilizers under irrigated conditions. Pak. J. Agri., Agril. Engg., Vet. Sci. 29 (2),114-125.

Barr, R., B"ottger, M. and Crane, F.L. (1993) The effect of boron on plasma membrane electron transport and associated proton secretionby cultured carrot cells. Biochem. Mol. Biol. Int. 31,31-39.

Bellaloui, N., Abbas, H.K., Gillen, A.M. and Abel, C.A (2009a) Effect of glyphosate boron application on seed composition and nitrogen metabolism in glyphosate- resistant soybean. Journal of Agriculture and Food Chemistry, 57, 9050-9056

Bellaloui, N., Hu, Y., Mengistu, A., Kassem, M.A. and Abel, C.A. (2013) Effects of foliar boron application on seed composition, cell wall boron, and seed $\delta 15 \mathrm{~N}$ and $\delta 13 \mathrm{C}$ isotopes in water-stressed soybean plants. Frontiers in Plant Nutrition, 4, $1-12$.

Bolãnos, L., Mateo, P. and Bonilla, I. (1993) Calciummediated recovery of boron deficient Anabaena sp. PCC 7119 grown under nitrogen fixing conditions. J. Plant Physiol. 142,513-17.

Bola nos, L., Brewin, N.J. and Bonilla, I. (1996) Effects of boron on Rhizobium-Legume cell-s interactions and nodule development. Plant Physiol. 110,1249-58.

Bolaños,L., Lukaszewski, K., Bonilla, I. and Blevins, D. (2004a) Why boron? Plant Physiol. Biochem. 42, 907-912.

Bonilla, I., Mergold-Villasẽnor, C., Campos, M.E. 
S'anches N. and $\mathrm{P}^{\prime}$ erez, H. et al. (1997) The aberrant cell walls of boron deficient bean root nodules have no covalentlyboundhydroxyproline/ proline-rich proteins. Plant Physiol. In press

Brown, J.C. (1979) Effects of boron stress on copper enzyme activity in tomato. J. Plant Nutr. 1, 39-53.

Cakmak, I., Kurz, H. and Marschner, H. (1995) Shortterm effects of boron, germanium and high light intensity on membrane permeability in boron deficient leaves of sunflower. Physiol. Plant. 95, $11-18$.

Cakmak, I. and Römheld, V. (1997) Boron deficiencyinduced impairments of cellular functions in plants. Plant Soil, 193, 71-83.

Camacho-Cristóbal, J.J., Anzelotti, D. and GonzálezFontes, A. (2002) Changes in phenolic metabolism of tobacco plants during short-term boron deficiency. Plant Physiol.Biochem. 40, 997-1002.

Camacho-Cristóbal, J.J., Maldonado, J.M. and González-Fontes, A. (2005) Boron deficiency increasesputrescine levels in tobacco plants J. Plant Physiol. 162, 921-928.

Camacho-Cristóbal, J.J. and González-Fontes, A. (2007) Boron deficiency decreases plasmalemma $\mathrm{H}+$-ATPase expression and nitrate uptake, and promotes ammonium assimilation into asparagine in tobacco roots. Planta, 226, 443-451.

Camacho-Cristóbal, J.J., Herrera-Rodríguezm, M.B., Beato, V.M., Rexach, J., Navarro-Gochicoa, M.T., Maldonado, J.M. and González-Fontes, A. (2008) The expression of several cell wall-related genes in arabidopsis roots is down-regulated under boron deficiency. Env. Exp. Bot. 63, 351-358.

Carpita, N.C. (1987) The biochemistry of the 'growing' plant cell wall. In: "Physiology of Cell Expansion During Plant Growth", D.J. Cosgrove, D.P. Knievel (Ed.), pp. 28-45. Rockville, MD: Am. Soc. Plant Physiol.

Casassa, E.Z., Sarquis, A.M. and Van Dyke, C.H. (1986) The gelation of polyvinyl alcohol with borax. A novel class participation experiment involving the preparation and properties of a "slime." J. Chem. Educ.63,57-60.

Clarkson, D.T. and Hanson, J.B. (1980) The mineral nutrition of higher plants. Annu. Rev. Plant Physiol. Plant Mol. Biol. 31,239-98.

Corrales, I., Poschenrieder, C. and Barceló, J. (2008) Boron-induced amelioration of aluminium toxicity in a monocot and a dicot species. J. Plant Physiol. 165, 504-513.

Dannel, F., Pfeffer, H. and Römheld, V. (2002)Update on boron in higher plant - uptake, primary translocation and compartmentation. Plant Biol. 4, 193-204.
Dell, B., Brown, P.H. and Bell, R.W. (Ed.) (1997) "Boron in Soils and Plants: Reviews". Dordrecht, Kluwer. 219 pp.

Dordas, C. and Brown, P.H. (2001) Permeability of boric acid across lipid bilayers and factors affecting it. J. Membr. Biol. 175, 95-105.

Dordas, C., Chrispeels, M.J. and Brown, P.H. (2000) Permeability and channel-mediated transport of boric acid across membrane vesicles isolated from squash roots. Plant Physiol. 124, 1349-1361.

Erike, P. and Nelson, S. (2012) Boron deficiency of palms in Hawaii. Plant Disease, April PD -83.

Fleischer, A., O'Neill, M.A. and Ehwald, R. (1999) The pore size of non-graminaceous plant cell walls is rapidly decreased by borate ester cross-linking of the pectic polysaccharide rhamnogalacturonan II. Plant Physiol. 121, 829-838.

García-González, M,, Mateo, P. and Bonilla, I.(1990) Effect of boron deficiency on photosynthesis and reductant sources and their relationship with nitrogenase activity in Anabaena PCC 7119. Plant Physiol. 93, 560-565.

Gauch, H.G. and Dugger, W.M. Jr. (1954) "The Physiological Action of Boron in Higher Plants: A Reviewand Interpretation." College Park: Univ. Md., Agric. Exp. Stn.

Goldbach, H.E. (1984) Influence of boron nutrition on net uptake and efflux of 32P and 14C-glucose in Helianthus annuus roots and cell cultures of Daucuscarota. J. Plant Physiol. 118, 431-38.

Goldbach, H.E., Hartmann, D. and R"otzer, T. (1990) Boron is required for the ferricyanide- induced proton release by auxins in suspension-cultured cells of Daucus carota and Lycopersicon esculentum. Physiol. Plant. 80, 114-18

Goldbach, H.E. and Wimmer, M. (2007) Boron in plants and animals: Is there a role beyond cell-wall structure? J. Plant Nutr. Soil Sci. 170, 39-48.

Gonzales-Reyes, J.A., Alcain, F.J., Caler, J.A., Serrano, A. Cordoba, F. and Navas, P. (1994) Relationship between apoplastic ascorbate regeneration and the stimulation of root growth in Allium cepa L. Plant Sci. 100, 23-29.

González-Fontes, A., Rexach, J., Navarro-Gochicoa, M.T., Herrera-Rodríguez, M.B., Beato, V.M., Maldonado, J.M. and Camacho-Cristóbal, J.J. (2008) Is boron involved solely in structural roles in vascular plants? Plant Signal. Behav. 3, 24-26.

Gupta, U.C. (1979) Boron nutrition of crops. Adv. Agron. 31, 273-307.

Gupta Urvi and Solanki, H. (2013) Impact of boron deficiency on plant growth. Int. J. Bioassays, 2 (07), 1048-1050. 
Hidalgo, A., Garcia-Herdugo, G., Gonz'ales- Reyes, J.A., Morr'e, D.J. and Navas, P. (1991) Ascorbate free radical stimulates onion root growth by increasing cell elongation. Bot. Gaz. 152, 282-88

Hu, H., Brown, P.H. and Labavitch, J.M. (1996) Species variability in b.oron requirement is correlated with cell wall pectin. Journal of Experimental Botany, 47, 227-32.

Kasajima, I. and Fujiwara, T. (2007) Identification of novel Arabidopsis thaliana genes which are induced by high levels of boron. Plant Biotech. 24, 355-360.

Kobayashi, M., Matoh, T. and Azuma, J. (1996) Two chains of rhamnogalacturonan II are cross-linked by borate-diol ester bonds in higher plant cell walls. Plant Physiol. 110, 1017-1020.

Kobayashi, M., Mutoh, T. and Matoh, T. (2004) Boron nutrition of cultured tobacco BY-2 cells. IV. Genes induced under low boron supply. J. Exp. Bot. 55, 1441-1443.

Lewis, D.H. (1980) Boron, lignification and origin of vascular plants: A unified hypothesis. New Phytol. 84, 209-229.

Lovatt, C. J. and Dugger, W.M. (1984) Bonon in Biolology. In: "Biochemistry of the Essential Trace Elements" Frieden, E. (Ed). pp.389-421. PlenumNew York.

Marschner, H. (1995) "Mineral Nutrition of Higher Plants." ${ }^{\text {nd }}$ ed. Academic Press, San Diego, pp. 379396.

Matoh, T., Kawaguchi, S. and Kobayashi, M. (1996) Ubiquity of a borate-rhamnogalacturonan II complex in the cell walls of higher plants. Plant Cell Physiol. 37, 636-40.

Miwa, K., Takano, J. and Fujiwara, T. (2006) Improvement of seed yields under boron limiting conditions through overexpression of BOR1, a boron transporter for xylem loading, in Arabidopsis thaliana. Plant J. 46, 1084-1091.

Mortvedt, J. (2010) "Micronutrients in Crop Production, Overview of Micronutrients and their Sources". Colorado State Univ., Available at: http://www.backto-basics.net/archives/articles/pdf/micronutrients.

Nable, R.O., Bañuelos, G.S. and Paull, J.G. (1997)Boron toxicity. Plant Soil, 193, 181-198.

Nable, R.O., Cartwright, B. and Lance, R.C. (1990). enotypic differences in boron accumulation in barley: Relative susceptibilities to boron deficiency and toxicity. In: " Genetic Aspects of Plant Mineral Nutrition". El Bassam, N., Dambroth, M., Loughman, B. (Ed.). pp. 243-251, Kluwer Academic Publishers, Dordrecht, The Netherlands.
Noguchi, K., Ishii, T., Matsunaga, T., Kakegawa, K., Hayashi, H. and Fujiwara, T. (2003) Biochemical properties of the cell wall in the Arabidopsis mutant bor1-1 in relation to boron nutrition. J. Plant Nutr. Soil Sci. 166, 175-178.

O’Neill, M.A., Warrenfeltz, D., Kates, K. Pellerin, P., Doco, T. and Darvill, A.G. (1996) Rhamnogalacturonan-II, a pectic polysaccharide in the wallsof growing plant cell, forms a dimer that is covalently crosslinkedby a borate ester. In vitro conditions for the formation and hydrolysis of the dimer. J. Biol. Chem. 271, 22923 -22930.

O'Neill, M.A., Ishii, T., Albersheim, P. and Darvill, A.G. (2004)Rhamnogalacturonan II: structure and function of a borate cross-linked cell wall pectic polysaccharide. Annu. Rev. Plant Biol. 55,109-139.

Planchet, E., Rannou, O., Ricoult, C., Boutet-Mercey, S., Maia-Grondard, A. and Limami, A.M. (2011) Nitrogen metabolism responses to water deficit act through both abscisic acid (ABA)-dependent and independent pathways in Medicago truncatula during post- germination. Journal of Experimental Botany, 62 (2), 605-615.

Redondo-Nieto, M., Rivilla, R., El-Hamdaoui, A., Bonilla, I. and Bolaños, L. (2001) Boron deficiency affects early infection events in the pea-Rhizobium symbiotic interaction. Aust. J. Plant Physiol. 28, 819-823.

Reid, R. (2007b) Update on boron toxicity and tolerance in plants. In: "Advances in Plant and Animal Boron Nutrition"Xu, F., Goldbach, H.E., Brown, P.H., Bell, R.W., Fujiwara, T., Hunt, C.D., Goldberg, S., Shi, L. (Ed.). pp. 83-90, Springer, Dordrecht, The Netherlands .

Reid, R.J., Hayes, J.E., Post, A., Stangoulis, J.C.R., and Graham, R.D. (2004) A critical analysis of the causes of boron toxicity in plants. Plant Cell Environ. 25, 1405-1414.

Reinbott, T.M. and Blevins, D.G. (1995) Response of soybean to foliar-applied boron. and magnesium and soil-applied boron. J. Plant Nutr. 18,179-200.

Roessner, U., Patterson, J.H., Forbes, M.G., Fincher, G,B., Langridge, P. and Bacic, A. (2006) An investigation of boron toxicity in barley using metabolomics. Plant Physiol. 142, 1087-1101.

Ruiz, J.M., Baghour, M., Bretones, G., Belakbir, A. and Romero, L. (1998a) Nitrogen metabolism in tobacco plants (Nicotiana tabacum L.): role of boron as a possible regulatory factor. Int. J. Plant Sci. 159, 121126.

Ruiz, J.M., Rivero, R.M. and Romero, L. (2006) Boron increases synthesis of glutathione in sunflower plants subjected to aluminum stress. Plant Soil, 279, 25-30. 
Ryden, P., Sugimoto-Shirasu, K., Smith, A.C., Findlay, K., Reiter, W.D. and McCann, M.C. (2003) Tensile properties of Arabidopsis cell walls depend on both a xyloglucan 23 cross-linkedmicrofibrillar network and rhamnogalacturonan II-borate complexes. Plant Physiol. 132, 1033-1040.

Sarquis, A.M. (1986) Dramatization of polymeric bonding using slime. J. Chem. Educ. 63, 60-61.

Schon, M.K., Novacky, A. and Blevins, D.G. (1990) Boron induces hyperpolarization of sunflower root cell membranes and increases membrane permeability to KC. Plant Physiol. 93, 566-71

Shahzad, A.N. (2011) "The Role of Jasmonic Acid (JA) and Abscisic Acid (ABA) in Salt Resistance of Maize (Zea mays L.)."Justus Liebig University, Giessen

Shen, Z.G., Liang, Y.C. and Shen, K. (1993) Effect of boron on the nitrate reductase-activity in oilseed rape plants. J. Plant Nutr. 16, 1229-1239.

Shkolnik, M.Y. (1984) "Trace Elements in Plants."New York, Elsevier.

Shorrock, V. M. (1997) The occurrence and correction of boron deficiency. Plant and Soil,193(1-2),121-148.

Stangoulis, J.C.R., Reid, R.J., Brown, P.H. and Graham, R.D. (2001) Kinetic analysis of boron transport in Chara. Planta, 213 (1), 142-146.

Sutton, T., Baumann, U., Hayes, J., Collins, N.C., Shi B.J., Schnurbusch, T., Hay, A., Mayo, G., Pallotta, M., Tester, M. and Langridge, P. (2007) Borontoxicity tolerance in barley arising from efflux transporter amplification. Science, 318, 1446-1449.

Takano, J., Noguchi, K., Yasumori, M., Kobayashi, M., Gajdos, Z., Miwa, K., Hayashi, H., Yoneyama, T. and
Fujiwara, T. (2002) Arabidopsis boron transporter for xylem loading. Nature, 420, 337-340.

Takano, J., Miwa, K., Yuan, L.X., von Wiren, N. and Fujiwara, T. (2005) Endocytosis and degradation of BOR1, a boron transporter of Arabidopsis thaliana, regulated by boron availability. Proc. Natl. Acad. Sci. USA 102, 12276-12281.

Takano, J., Wada, M., Ludewig, U., Schaaf, G., von Wirén, N. and Fujiwara, T. (2006) The Arabidopsis major intrinsic protein NIP5;1 is essential for efficient boron uptake and plant development under boron limitation. Plant Cell, 18, 1498-1509.

Tanaka, M. and Fujiwara, T. (2007) Physiological roles and transport mechanisms of boron: perspectives from plants. Eur. J. Physiol. (DOI 10.1007/s00424007-0370-8).

Trivedi, A. K. (2015) Boron: An Essential Element Needs Attention ICAR-National Bureau of Plant Genetic Resources, Regional Station Bhowali, Nainital (Uttarakhand) - 263132, district - Nainital (Uttarakhand).

Walsh, T. and Golden, J.D. (1953) The boron status of Irish soils in relation to the occurrence of boron deficiency in some crops in acid and alkaline soils. Int. Soc. Soil Trans. II, 167-71.

Yamauchi, T., Hara, T. and Sonoda Y. (1986) Distribution of calcium and boron in the pectin fraction of tomato leaf cell wall. Plant Cell Physiol. 27, 729-32

Yu, Q., Baluska, F., Jasper, F., Menzel. D. and Goldbach, H.E. (2003) Short-term boron deprivation enhances levels of cytoskeletal proteins in maize, but not zucchini, root apices. Physiol. Plant. 117, 270-278. 


\section{دور عنصر البورون في نمو وتطور النبات}

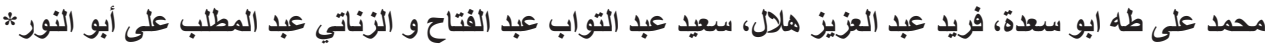

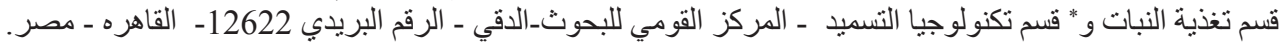

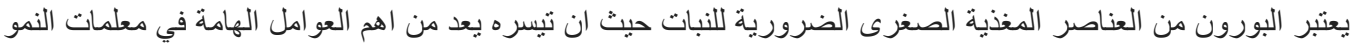

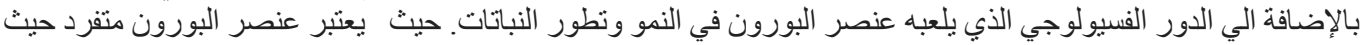

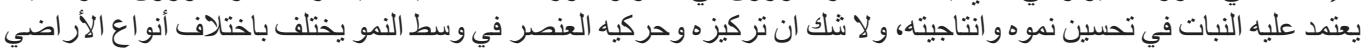

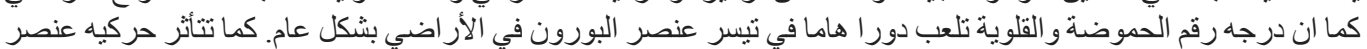

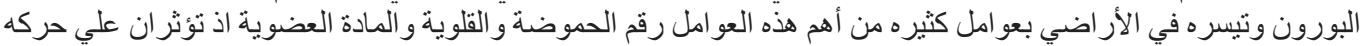

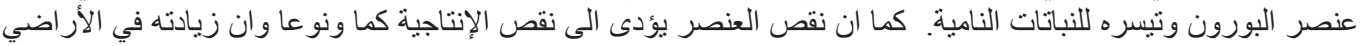

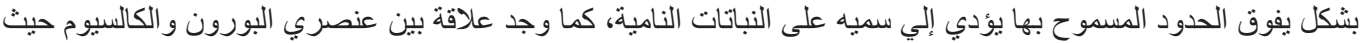

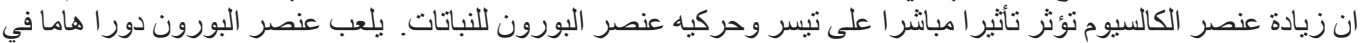

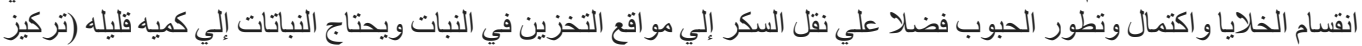
قليل) للنمو اذ ما قورن بالعناصر الخور الأولية الأخرى.

يهذف هذا البحث المرجعي إلي فهم الدور الفسيولوجي لعنصر البورون في النبات. 